
5 Rathna Venkata Naga Gundloori ${ }^{1,3}$, Mahesh S. Dharne ${ }^{1,2^{*}}$

6

17

18

19

20

21

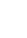

12

13

Number of pages: 18

Number of figures: 14

Number of tables: 2

17

\title{
Supplementary information of
}

\section{One-pot bioconversion of tomato waste into Poly-gamma-glutamic acid $(\gamma-$ PGA) biopolymer by a novel biocatalyst}

Pranav G. Nair ${ }^{1,2}$, Emmanuel Joseph ${ }^{1,3}$, Naresh Killi ${ }^{1,3}$, Sravanya Konchada ${ }^{1,3}$, Anuya Nisal ${ }^{1,3}$,

${ }^{1}$ Academy of Scientific and Innovative Research (AcSIR), Ghaziabad , India-201002.

${ }^{2}$ National Collection of Industrial Microorganisms (NCIM), Biochemical Science Division, CSIR-National Chemical Laboratory, Pune, India-411008.

${ }^{3}$ Polymer Science and Engineering Division, CSIR-National Chemical Laboratory, Pune, India-411008. 


\section{TABLE OF CONTENT}

\begin{tabular}{|c|c|c|}
\hline Sr.No. & Content & Page \\
\hline 1 & General & S3 \\
\hline 1.1 & Material and methods & S3 \\
\hline 1.2 & Instruments & S3 \\
\hline 2 & Media Optimization studies & S3 \\
\hline 2.1 & Isolation of $\gamma$-PGA producing strains & S4 \\
\hline 2.2 & Screening for $\gamma$-PGA production & S4 \\
\hline 2.3 & Molecular identification of $\gamma$ - PGA producing strains & S4 \\
\hline 2.4 & Effect of inoculum on $\gamma$-PGA production & S5 \\
\hline 2.5 & Effect of time on the production of $\gamma$-PGA & S6 \\
\hline 2.6 & Effect of thetemperature on the production of $\gamma$-PGA & S6 \\
\hline 2.7 & Effect of $\mathrm{pH}$ on the production of $\gamma$-PGA & S6 \\
\hline 2.8 & Effect of different carbon sources on $\gamma$-PGA production & S6 \\
\hline 2.9 & Effect of different nitrogen sources on $\gamma$-PGA production & S7 \\
\hline 3 & Waste utilization & S8 \\
\hline 3.1 & $\gamma$-PGA production from the Tomato waste & S8 \\
\hline 3.2 & $\begin{array}{l}\text { Comparative study on } \gamma \text {-PGA production from the synthetic(B) and natural(Tomato } \\
\text { waste)medium }\end{array}$ & S9 \\
\hline 3.3 & Scale-up of $\gamma$-PGA production in 1 litrefermentor & S9 \\
\hline 4 & Characterization studies & S9 \\
\hline 4.1 & Detection of glutamic acid monomers by Thin Layer Chromatography(TLC) & S9 \\
\hline 4.2 & Fourier Transform Infrared Spectroscopy (FTIR) & S10 \\
\hline 4.3 & Differential Scanning Calorimetry (DSC) & S11 \\
\hline 4.4 & Thermogravimetric analysis (TGA) & S12 \\
\hline 4.5 & HPLC analysis to detect the presence of glutamic acid, sugars and citric acid & S13-S15 \\
\hline 4.6 & Composition of synthetic production media(B, B1 and B2 media) an & S16 \\
\hline 4.7 & Composition of tomato waste media (TW1\& TW2) & S16 \\
\hline 5 & References & S17 \\
\hline
\end{tabular}




\section{General}

Materials and methods

All the synthetic medium components were purchased from Hi-media. Rotten tomatoes and natural honey were procured from the local market of Pune, India. The standard $\gamma$-PGA was purchased from Sigma Aldrich(CAS Number:208106-41-6). Thin Layer Chromatograpgy(TLC) analysis was performed with Merck Silica gelTLC plates. Rotten tomatoes were concentrated using rota vapor. Hydrolysis of $\gamma$-PGA was carried out using an oil bath. The optical density (OD) of the bacterial cells was maintained using a UV-Vis spectrophotometer at $600 \mathrm{~nm}$. The synthesized $\gamma$-PGA was dried using a lyophilizer.

Instruments

Molecular identification was carried out with ABI 3500xL genetic analyzer. HPLC analysis was performed using Thermo Scientific, Dionex Ultimate 3000 system. Scale-up studies were conducted using Fermentor.

Fourier Transform Infrared (FTIR)Spectroscopy: The $\gamma$-PGA was characterized in ATR mode using a Bruker Tensor II spectrophotometer equipped with a diamond crystal probe

Differential Scanning Calorimetry (DSC):Measurements were performed on $\gamma$-PGA in an

Thermogravimetric analysis (TGA): The thermal stability of $\gamma$-PGA was studied using a Thermogravimetric analyzer. A thermal gravimetric curve was obtained under a broad temperature range of $25-900^{\circ} \mathrm{C}$ at a ramp rate of $10^{\circ} \mathrm{C} / \mathrm{min}$ in a nitrogen atmosphere. About 2-5 mg of sample was used, and analysis was performed on Perkin Elmer STA 6000 (Pyris Thermal Analysis Manager) $)^{2}$.

Nuclear Magnetic Resonance ( NMR): The purity of the $\gamma$ - PGA produced from synthetic and 55 tomato waste mediawas determined by ${ }^{1} \mathrm{H}$ NMR with reference to STD $\gamma$ - PGA (Sigma Aldrich).

$5610 \mathrm{mg} / \mathrm{mL}$ sample was dissolved in $\mathrm{D}_{2} \mathrm{O}$ (deuterium oxide) and recorded ${ }^{1} \mathrm{H}$ NMR spectra using 57 Bruker AV $500 \mathrm{MHz}$. 


\section{Media optimization studies}

\section{Isolation of $\gamma$ - PGA producing strains}

61

62

Bacteria were isolated from natural honey by serially diluting it and spread plated onto nutrient agar mediumconsisting of (g/L): Peptone, 5; Sodium chloride, 5; Beef extract, 1.5; Yeast extract, 1.5; Agar, $15^{3}$. The plates were incubated at $37^{\circ} \mathrm{C}$ for $24 \mathrm{~h}$.

\section{Screening for $\gamma$-PGA production}

Isolates were grown in synthetic(B medium) production mediumcontaining (g/L); glucose, 40; citric acid, 10; L-glutamic acid, 20; $\mathrm{NH}_{4} \mathrm{Cl}, 6 ; \mathrm{K}_{2} \mathrm{HPO}_{4}, 1 ; \mathrm{MgSO}_{4}, 7 \mathrm{H}_{2} \mathrm{O}, 0.5 ; \mathrm{CaCl}_{2} .2 \mathrm{H}_{2} \mathrm{O}, 0.2$; $\mathrm{FeCl}_{3} .7 \mathrm{H}_{2} \mathrm{O}, 0.03$; at $\mathrm{pH}-7.5$ and incubated at $28^{\circ} \mathrm{Cat} 180 \mathrm{rpm}$ for $24 \mathrm{~h}$. Based on the viscosity of fermented broth, strains were selected for further studies. The broth was centrifuged at 10000 rpm for 30 min to obtain supernatant, to which four volumes of ice-cold methanol was added to get fibrous precipitate, presumably $\gamma$-PGA. The precipitate was dissolved in deionized water and desalted by dialysis using $14 \mathrm{kDa}$ cellulose membrane and finally subjected to lyophilization ${ }^{4}$.

\section{Molecular identification of $\gamma$ - PGA producing strains}

DNA isolation was carried out by the CTAB method ${ }^{5}$. The polymerase chain reaction(PCR) was carried out using $530 \mathrm{~F}$ and $800 \mathrm{R}$ primers in a final reaction mixture of $50 \mu \mathrm{l}$, which consisted of template DNA: $1 \mu \mathrm{l}$, PCR buffer: $5 \mu \mathrm{l}$, dNTPs: $5 \mu 1$, forward primer(530F), and reverse primer (800R): $2.5 \mu \mathrm{l}$ each, Taq polymerase: $0.5 \mu \mathrm{l}$, PCR water: $33.5 \mu 1$. The PCR was run under the following cycling conditions: Initial denaturation at $94{ }^{\circ} \mathrm{C}$ for $5 \mathrm{~min}$, followed by 34 cycles of 94 ${ }^{\circ} \mathrm{C}$ for $30 \mathrm{sec}$, annealing at $55{ }^{\circ} \mathrm{C}$ for $30 \mathrm{sec}$, extension at $72{ }^{\circ} \mathrm{C}$ for $1: 30 \mathrm{~min}$ and a final extension at $72{ }^{\circ} \mathrm{C}$ for $10 \mathrm{~min}^{6}$. Purification of the PCR product was carried out using the PEG-NaCl protocol. The DNA sequencing was performed on ABI 3500XL genetic analyzer. The 16S rRNA gene sequence obtained was searched for closely related species from the NCBI database by using the https://blast.ncbi.nlm.nih.gov/Blast.cgi. The evolutionary history was inferred using the Neighbor-Joining method. Evolutionary analyses were conducted using MEGA6 software. 


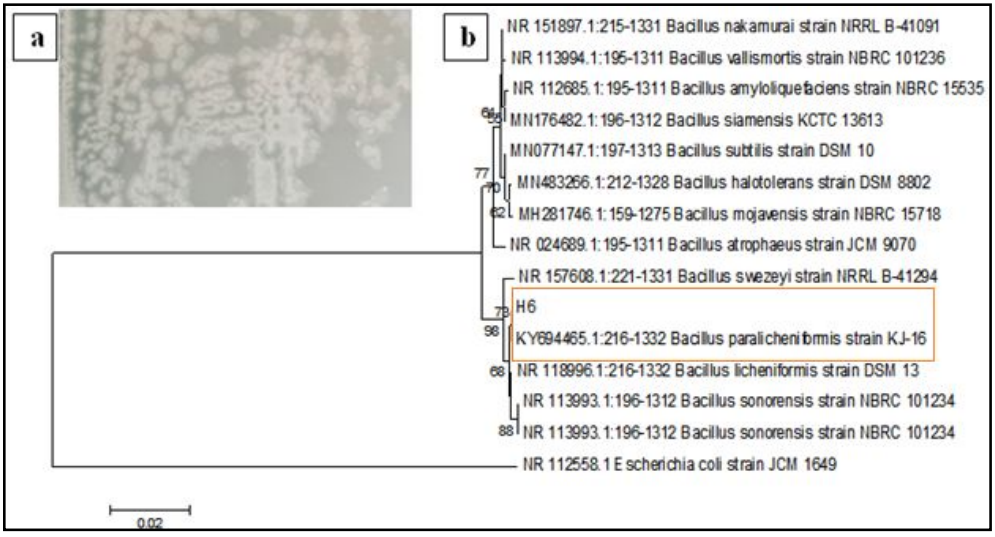

Figure S1.a, Growth of H6 isolate on nutrient agar plate. b,Molecular phylogenetic analysis by Neighbor-Joining method.The H6 isolate showed $99 \%$ similarity to Bacillus paralicheniformis $\mathrm{KJ}-16 \mathrm{~T}$.

91 Effect of inoculum on $\boldsymbol{\gamma}$-PGA production using synthetic medium: A loopful of cells were inoculated in $50 \mathrm{~mL}$ of nutrient broth in $250 \mathrm{~mL}$ Erlenmeyer flask and incubated for $24 \mathrm{hrs}$ at $28^{\circ} \mathrm{C}$. The cells were diluted such that the final $\mathrm{OD}_{600}$ was $\mathrm{OD}_{600} 1.0, \mathrm{OD}_{600} 2.0, \mathrm{OD}_{600} 3.0$. The synthetic production medium was inoculated with $1 \%, 2 \%, 3 \%$ inoculum of $\operatorname{OD}_{600}(1.0,2.0,3.0)$ and incubated at $28^{\circ} \mathrm{C}$ with $180 \mathrm{rpm}$ for $24 \mathrm{~h}$. All experiments were carried out in triplicates.

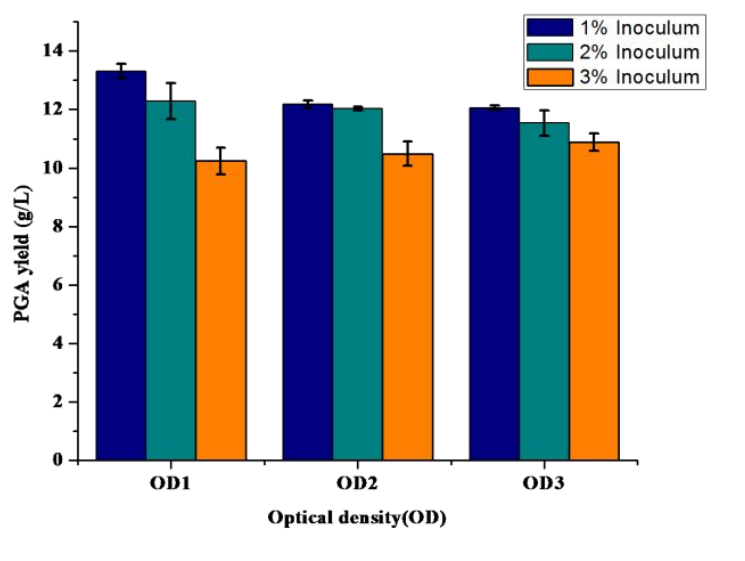

Figure S2. depicts effect of inoculum size $\left(O D_{600}\right)$ on $\gamma$ PGA production at $24 \mathrm{~h}$.

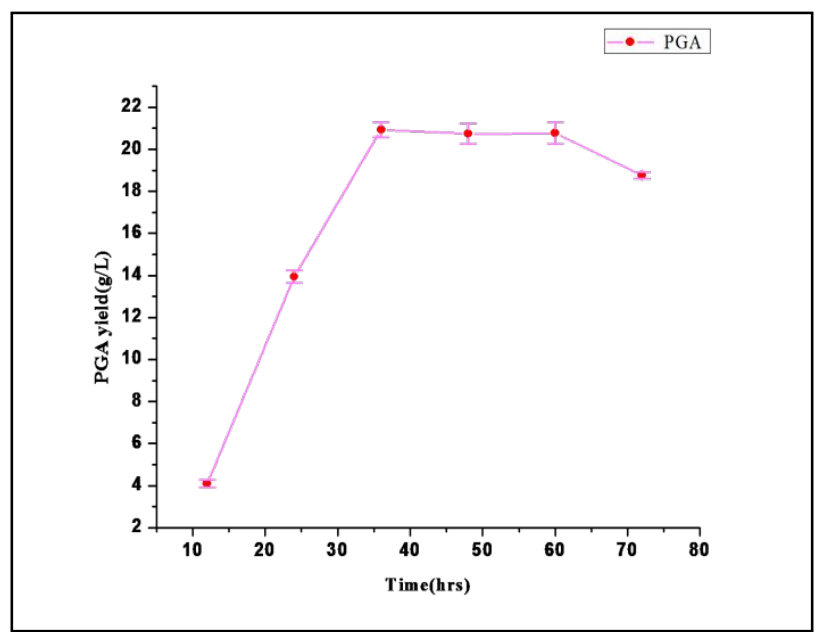

Figure S3. depicts the effect of time on $\gamma$-PGA production. 

$\mathrm{pH}$ of the medium was adjusted using $10 \mathrm{~N} \mathrm{NaOH}$.

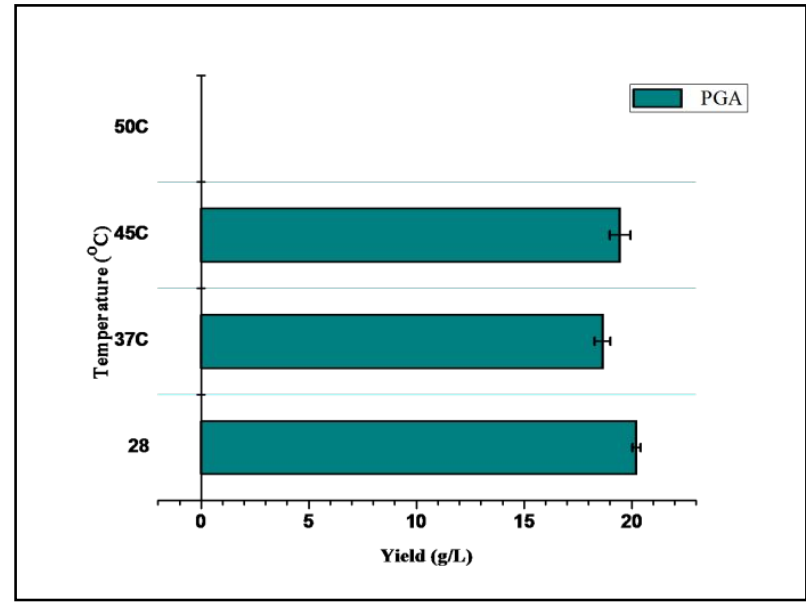

Figure S4. depicts the effect of temperature on $\gamma$-PGA production.

Effect of time on the production of $\gamma$-PGA: $1 \%$ inoculum of $\mathrm{OD}_{600} 1.0$ was added to synthetic production medium and incubated at $28^{\circ} \mathrm{C}$ for the following time (12h, 24h, 36h, $48 \mathrm{~h}, 60 \mathrm{~h}, 72 \mathrm{~h}$ ). The resulting fermentation broth was centrifuged at $10000 \mathrm{rpm}$ for $30 \mathrm{~min}$ to which ice-cold methanol was added, and the obtained biopolymer was lyophilized after dialysis.

Effect of temperature on the production of $\gamma$-PGA: Inoculum of $1 \%$ was added to synthetic production medium $(\mathrm{pH} 7.5)$ and incubated for $36 \mathrm{~h}$ at temperature range $\left(28^{\circ} \mathrm{C}, 37^{\circ} \mathrm{C}, 45^{\circ} \mathrm{C}\right.$, $50^{\circ} \mathrm{C}$ ). The fermented broth was centrifuged, and four volumes of ice-cold methanol was added for the precipitation of $\gamma$-PGA. The obtained polymer was dried bylyophilisation for $24 \mathrm{~h}$.

Effect of $\mathbf{p H}$ on the production of $\boldsymbol{\gamma}$-PGA: Inoculum of $1 \%$ was added to synthetic production medium with $\mathrm{pH}$ range ( 4.5 to 10 ) and incubated at $28^{\circ} \mathrm{C}$ for $36 \mathrm{~h}$ under shaking conditions. The

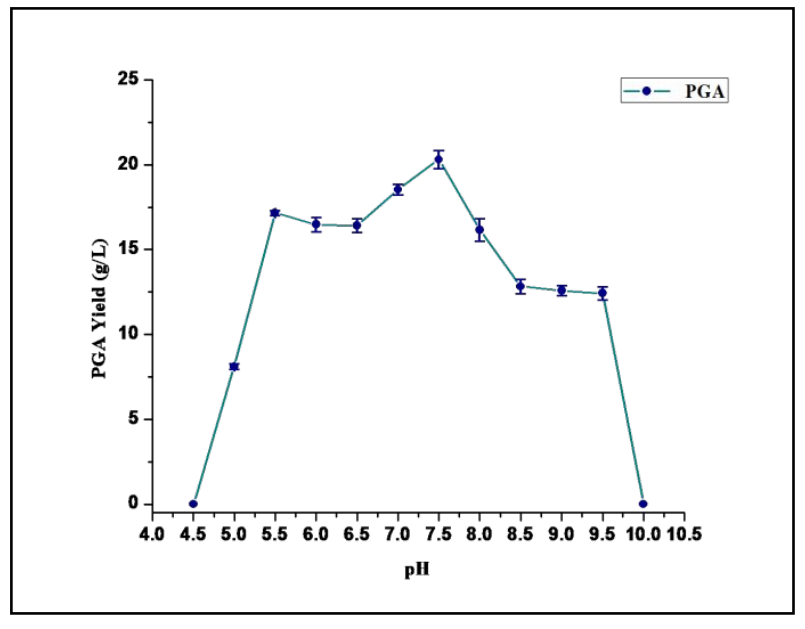

Figure S5. depicts the effect of $\mathrm{pH}$ on $\gamma$-PGA production.

Effect of different carbon sources on $\boldsymbol{\gamma}$-PGA production: Different carbon sources such as glucose, fructose, sucrose, trehalose, lactose, xylose, etc., were added into the production medium with the concentration of $40 \mathrm{~g} / \mathrm{L}$ to investigate $\gamma$-PGA production. The $\mathrm{pH}$ of the medium was adjusted to 7.5 using $10 \mathrm{~N} \mathrm{NaOH}$. $1 \%$ inoculum of $\mathrm{OD}_{600} 1.0$ was added to this medium followed by incubation at $28^{\circ} \mathrm{C}$ for $36 \mathrm{~h}$ under shaking conditions. 
Figure S6. depicts the effect of various carbon sources on $\gamma$-PGA production.

Effect of different nitrogen sources on $\boldsymbol{\gamma}$-PGA production: Four organic nitrogen sources

131 (peptone, tryptone, yeast extract, beef extract) and five inorganic nitrogen sources (ammonium 132 sulfate, ammonium chloride, ammonium citrate, ammonium acetate, and ammonium nitrate) 133 with the concentration of $6.0 \mathrm{~g} / \mathrm{L}$ were used to investigate $\gamma$-PGA production after $36 \mathrm{~h}$. Inoculum 134 of $1 \%$ was added to this production medium and incubated at $28^{\circ} \mathrm{C}$ for $36 \mathrm{~h}$ under shaking 135 conditions. 


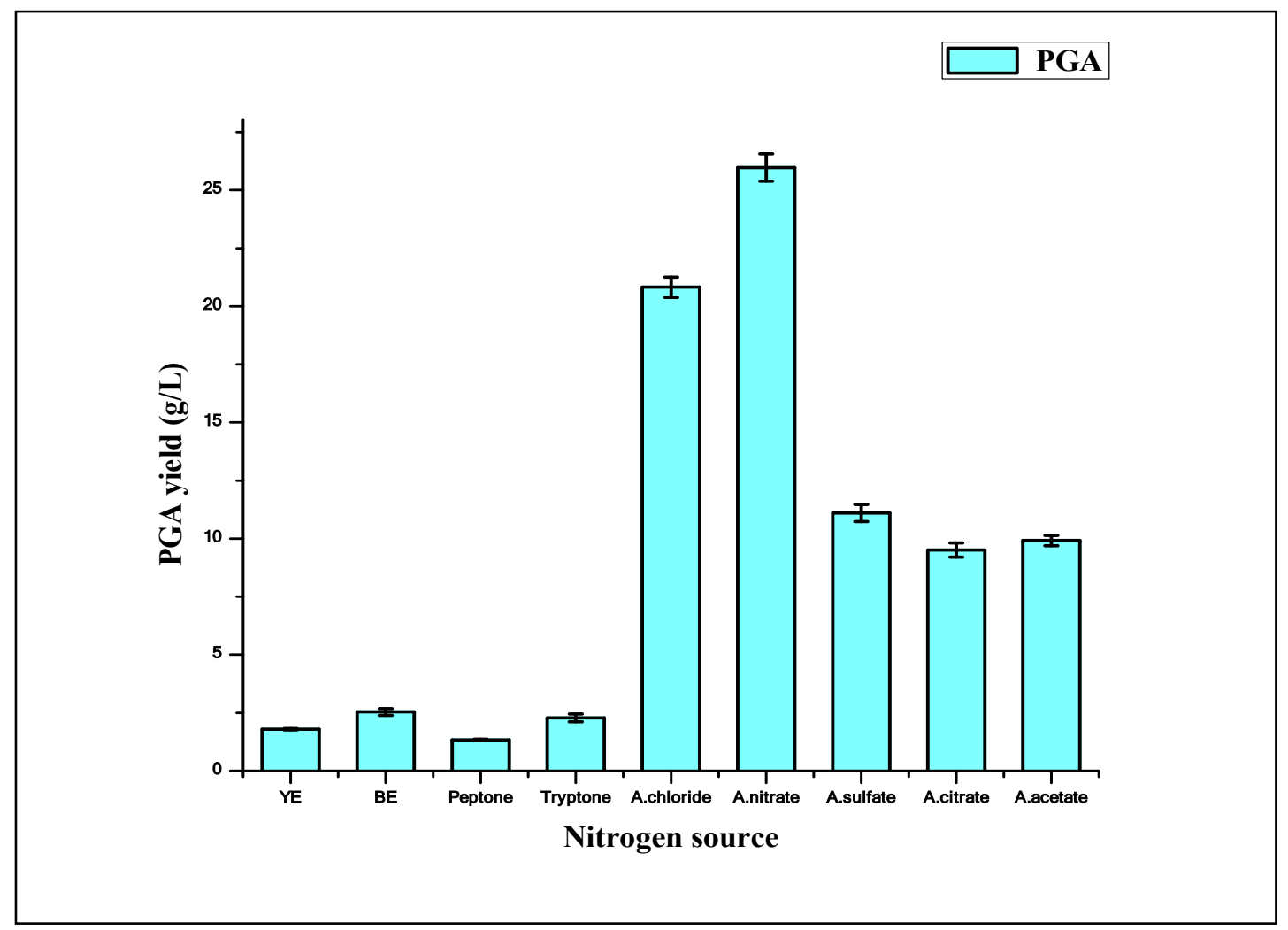

147

Figure S7. depicts the effect of various nitrogen sources on $\gamma$-PGA production.

152 medium for substituting glucose, L-glutamic acid and citric acid for $\gamma$ - PGA production. Rotten

153 tomatoes were grinded, and the supernatant was collected after centrifugation at $5000 \mathrm{rpm}$ for 10 $154 \mathrm{~min}$. The supernatant was concentrated using rotavapor and ammonium nitrate, $0.6 \% ; \mathrm{K}_{2} \mathrm{HPO}_{4}$, $1551 \% ; \mathrm{MgSO}_{4}, 0.5 \% ; \mathrm{CaCl}_{2}, 0.2 \% ; \mathrm{FeCl}_{3}, 0.03 \%$ was added. The $\mathrm{pH}$ was adjusted to 7.5 by $10 \mathrm{~N}$ $156 \mathrm{NaOH} .1 \%$ inoculum of $\mathrm{OD}_{600} 1.0$ was added to this concentrated solution and incubated for $48 \mathrm{~h}$ 157 at $28^{\circ} \mathrm{C}$ and $180 \mathrm{rpm}$. medium by $\mathrm{H6}$ isolate: To check the efficacy of natural medium to completely replace synthetic medium, tomato waste was used directly without the addition of ammonium nitrate and trace

161 elements. As a control for synthetic medium, B1 medium was used without the addition of 
162 ammonium nitrate and trace elements (i.e. B2 medium). The $\mathrm{pH}$ of the medium was adjusted to

1637.5 using $10 \mathrm{~N} \mathrm{NaOHand} 1 \%$ inoculum of $\mathrm{OD}_{600} 1.0$ was added to this medium followed by

164 incubation at $28^{\circ} \mathrm{C}$ for $48 \mathrm{~h}$ at $180 \mathrm{rpm}$.

165 Scale-up of $\boldsymbol{\gamma}$-PGA production in 1 litrefermentor: Tomato waste was grinded, and the 166 supernatant was collected after centrifugation at $5000 \mathrm{rpm}$ for $10 \mathrm{~min}$. 5L of the supernatant was 167 evaporated to obtain a final volume of 1L.The $\mathrm{pH}$ of the medium was adjusted to 7.5 with $10 \mathrm{~N}$ $168 \mathrm{NaOH} .1 \%$ of the inoculum was added to the production medium in the fermentor. The initial 169 agitation and aeration were maintained at $250 \mathrm{rpm}$ and $1 \mathrm{vvm}$, respectively.The $\gamma$-PGA was 170 extracted after $48 \mathrm{~h}$ of fermentation at $28^{\circ} \mathrm{C}$ using four volumes of methanol.

\section{Characterization Studies}

\section{Detection of glutamic acid monomers by Thin Layer Chromatography(TLC)}

173 The $\gamma$-PGA(10mg)was hydrolyzed with $2 \mathrm{ml}$ of $6 \mathrm{~N} \mathrm{HCl}$ at $105^{\circ} \mathrm{C}$ for $4 \mathrm{~h}$ in a glass vial. Any 174 residualHClwas removed by evaporation in rotavapor followed by its dissolution in $1 \mathrm{~mL}$ of 175 deionized water. Amino acid was analyzed by TLC using butanol-acetic acid-water (12:5:3) as 176 the solvent system. The TLC was developed by spraying $20 \mathrm{~mL}$ of $0.2 \%$ ninhydrin in acetone, 177 followed by drying 7 . 
186 The functional groups characterization of $\gamma$-PGA was performed using FTIR spectroscopy using 187 Bruker Tensor II.

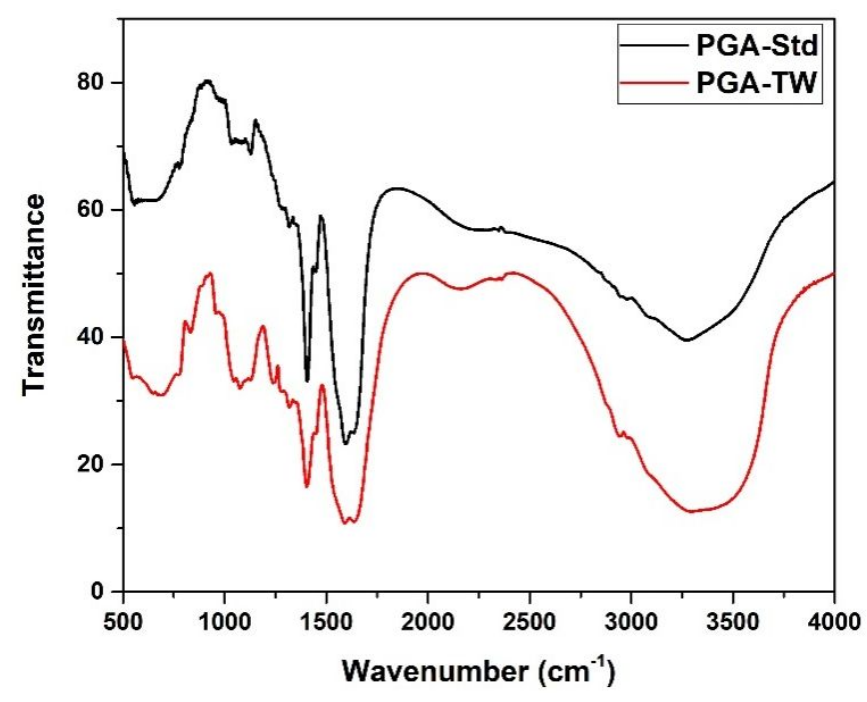

\begin{tabular}{|l|l|l|}
\hline Sr.No. & Functional Group & Peak Position \\
\hline 1 & N-H Bending & $3300-3700$ \\
\hline 2 & C-H Stretching & $2930-2955$ \\
\hline 3 & COOH & $1720-1730$ \\
\hline 4 & $\begin{array}{l}\text { Amide I (C=O) } \\
\text { Back bone Peptide }\end{array}$ & $1650-1620$ \\
\hline 5 & Amide II & $1550-1520$ \\
\hline
\end{tabular}

191

192 


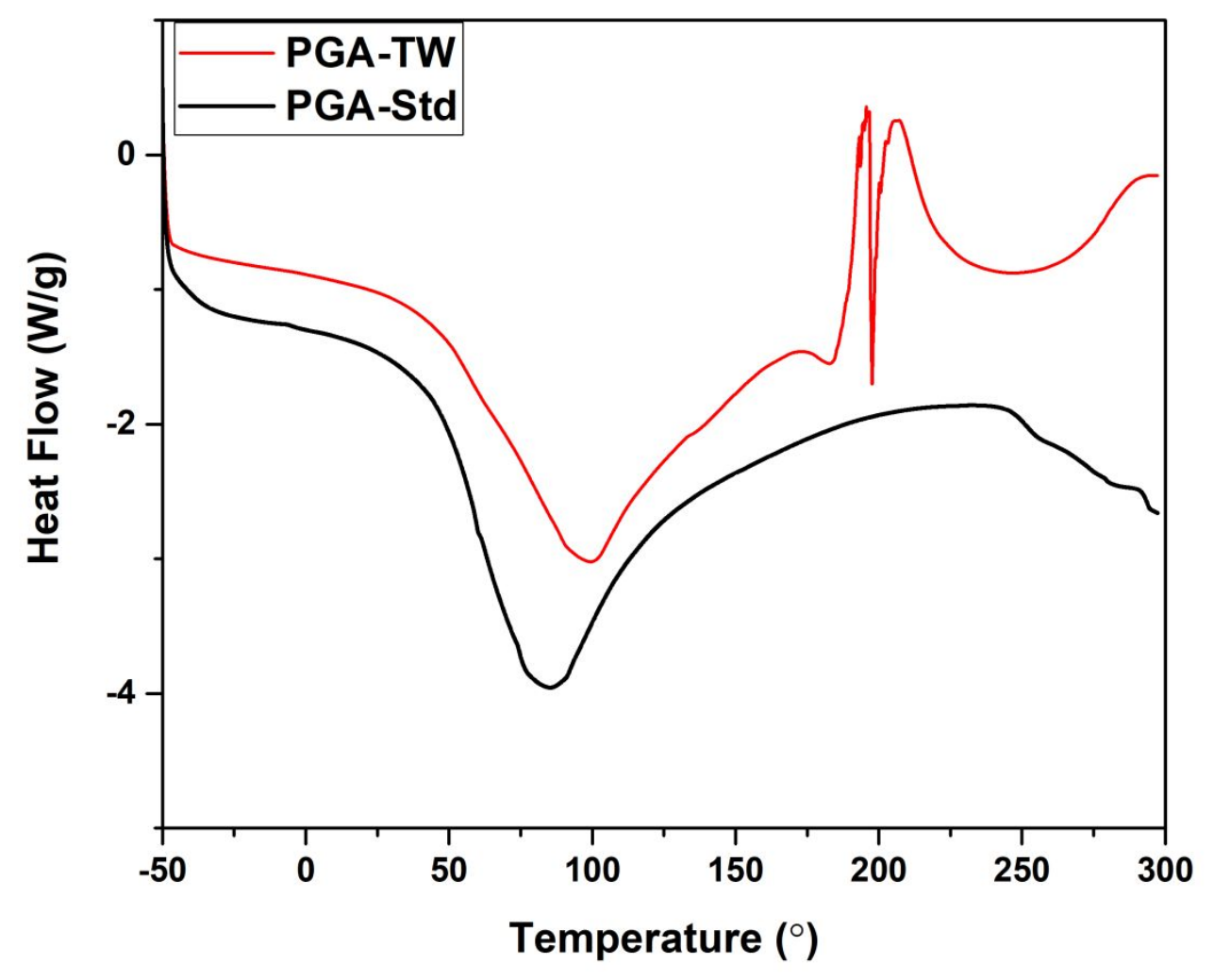

201

Figure S10. DSC analysis of $\gamma$-PGA from TW2 medium and STD $\gamma$-PGA.

203

204

205

206

207

208

209

210 
211 Thermogravimetric analysis (TGA):

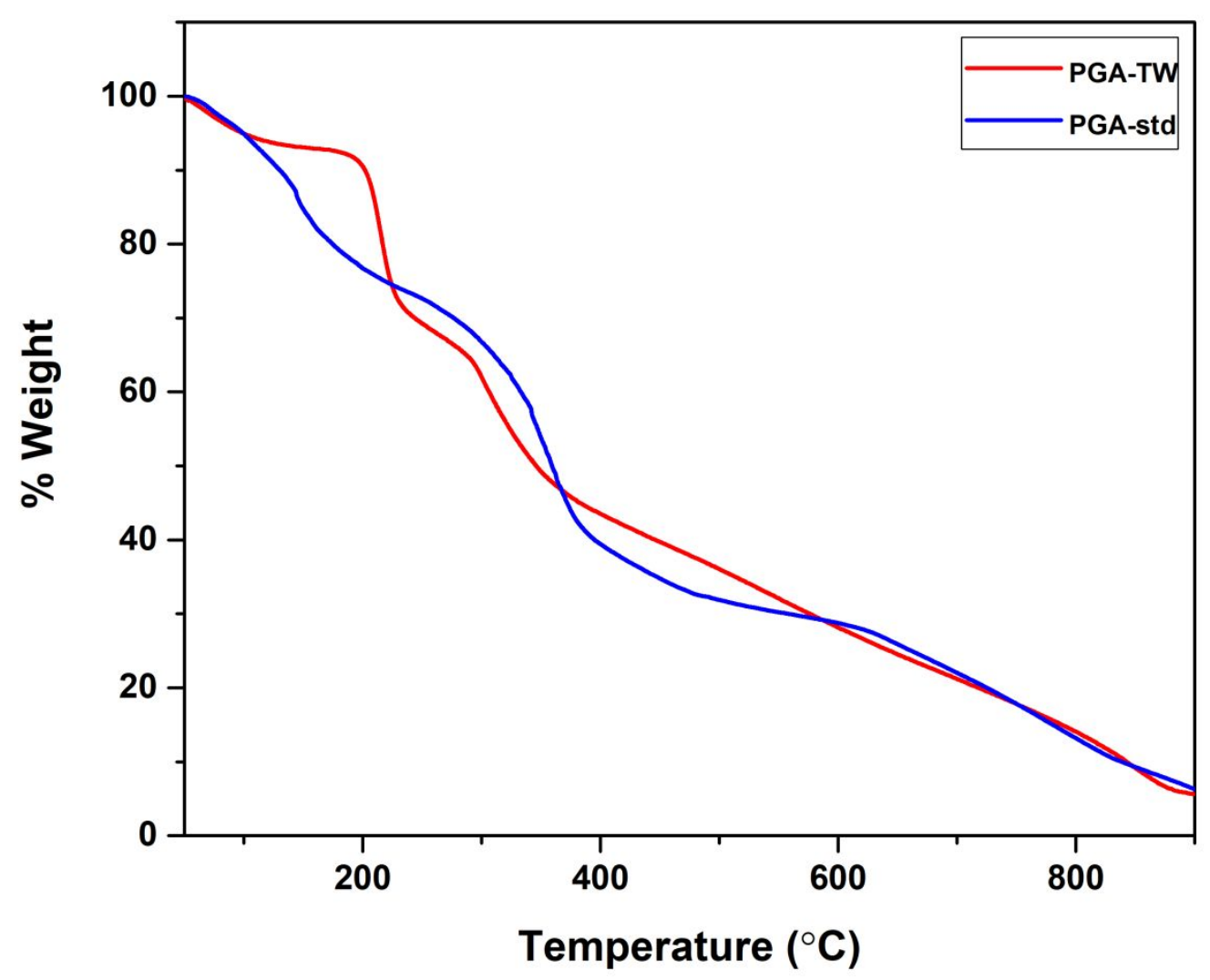

212

213

214

215

216

217

218

219

220

221

\section{4}

17

Figure S11. weight loss analysis of $\gamma$-PGA with temperature. 
222 HPLC analysis to detect the presence of glutamic acid, sugars and citric acid:Tomato waste

223 was grinded, and the supernatant was collected after centrifugation at $5000 \mathrm{rpm}$ for $10 \mathrm{~min}$. The 224 supernatant was concentrated $5 \mathrm{X}$ using rota vapor and then passed through 0.2 micron filter prior 225 to HPLC analysis. Standard glucose $(50 \mathrm{mg} / \mathrm{ml})$, L- glutamic acid $(10 \mathrm{mg} / \mathrm{ml})$, fructose $(50 \mathrm{mg} / \mathrm{ml})$ 226 and citric acid $(1 \mathrm{mg} / \mathrm{ml})$ was used as control. The detection of sugars was carried out usingYMC227 Poly amine II column $/ 5 \mu \mathrm{m}$; column size: $250 \times 4.6 \mathrm{~mm}$; Mobile Phase: $75 \%$ acetonitrile; detector: $228 \mathrm{RI}$; flow rate: $1 \mathrm{~mL} / \mathrm{min}^{8}$. The detection of L-glutamic acid was carried out using ChromeCore 229 C18 column $/ 5 \mu \mathrm{m}$; column size: $250 \times 4.6 \mathrm{~mm}$; mobile Phase: methanol: water: formic acid 230 (70:30:0.02); detector: UV; flow rate: $0.5 \mathrm{~mL} / \mathrm{min}^{9}$. The presence of organic acids was 231 studiedusingChromeCore $\mathrm{C} 18$ column $/ 5 \mu \mathrm{m}$; column size: $250 \times 4.6 \mathrm{~mm}$; mobile phase: $0.1 \%$ 232 orthophosphoric acid; detector: $\mathrm{UV}$; flow rate: $0.5 \mathrm{~mL} / \mathrm{min}^{10}$. 


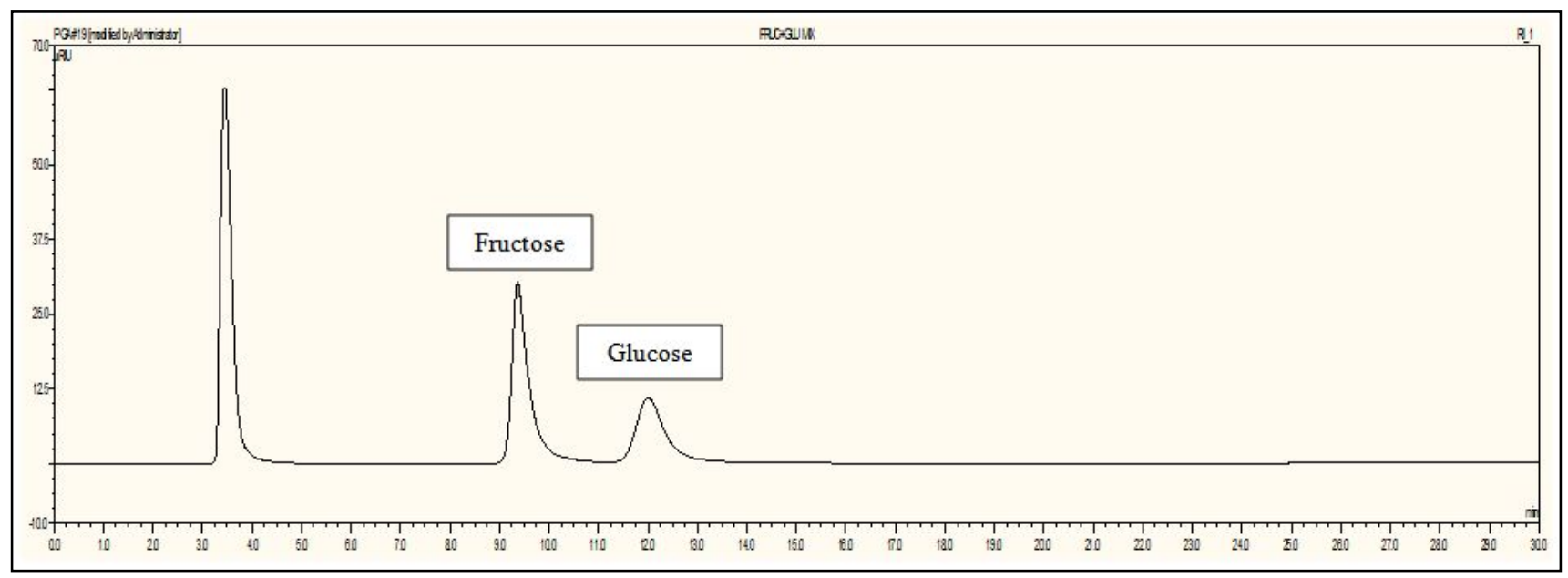

Figure S12a. depicts the HPLC analysis of standard sugars $(50 \mathrm{mg} / \mathrm{mL}$ fructose $+50 \mathrm{mg} / \mathrm{mL}$ glucose $)$.

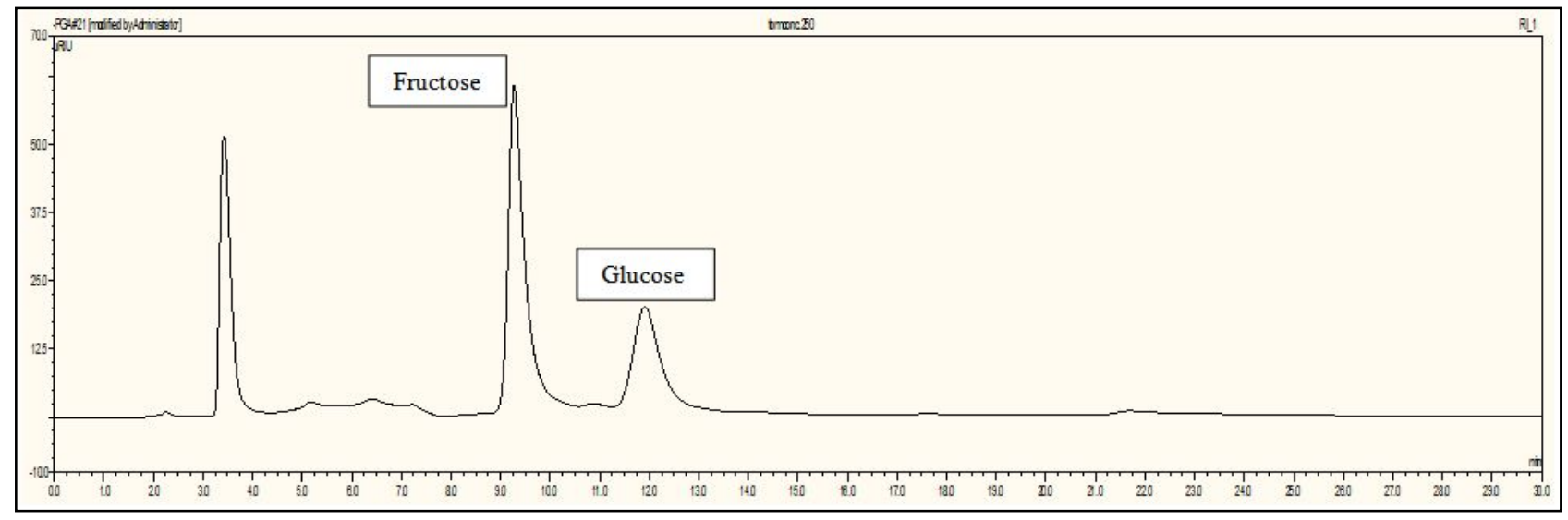

Figure $\mathrm{S12b}$. depicts the detection of sugars in $\mathrm{TW} 2$ medium (5X concentrated).

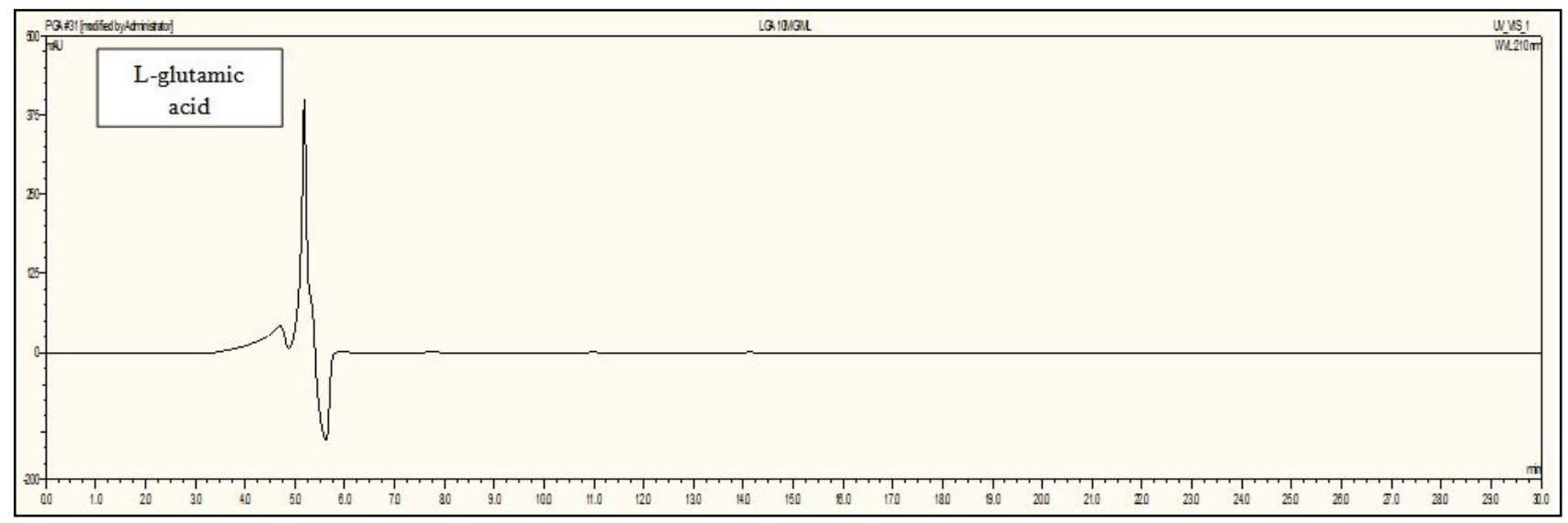

Figure S13a. depicts the HPLC analysis ofstandardL-glutamic acid (10mg/ml). 


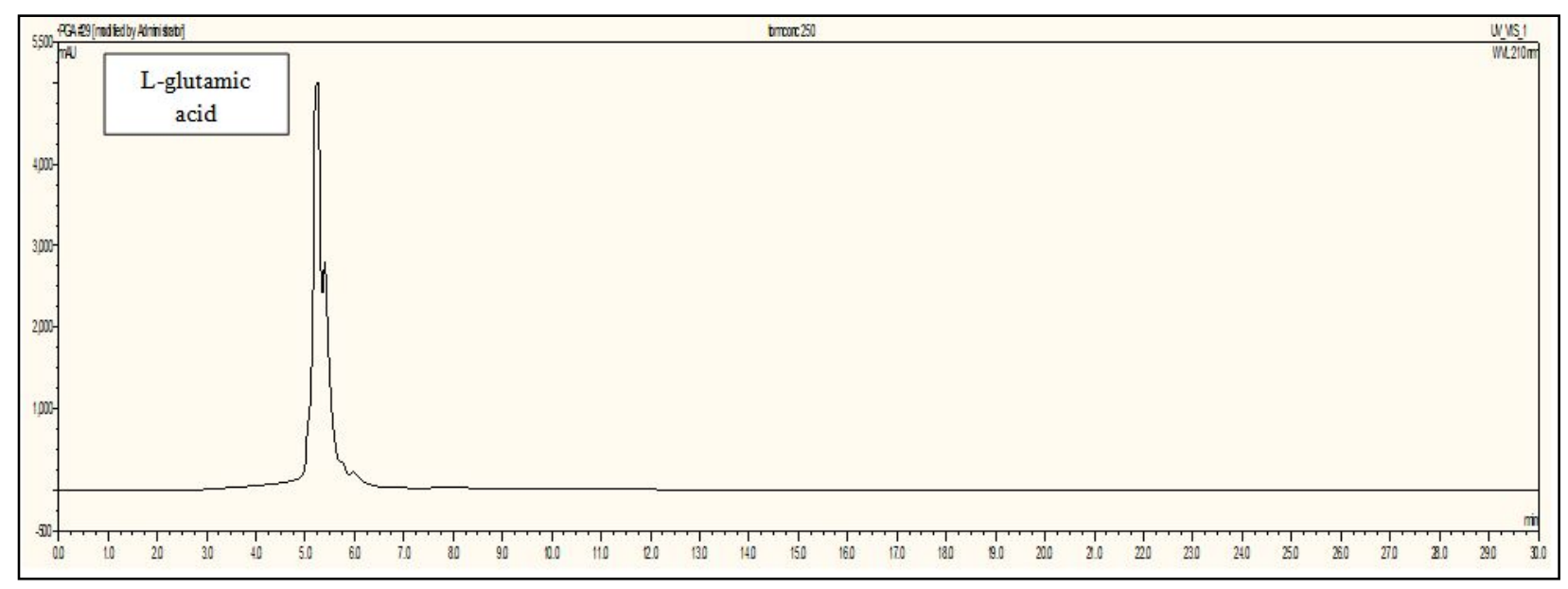

Figure S13b. depicts the detection of L-glutamic acid in TW2 medium (5X concentrated).

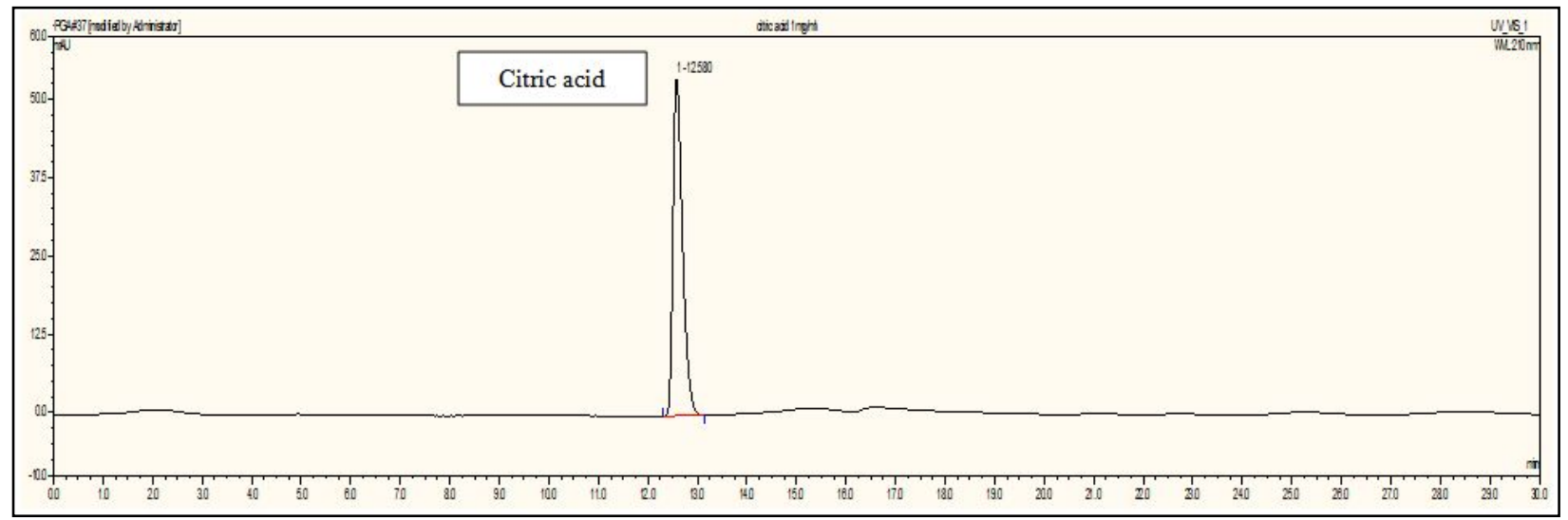

Figure S14a. depicts the HPLC analysis ofstandard citric acid $(1 \mathrm{mg} / \mathrm{ml})$.

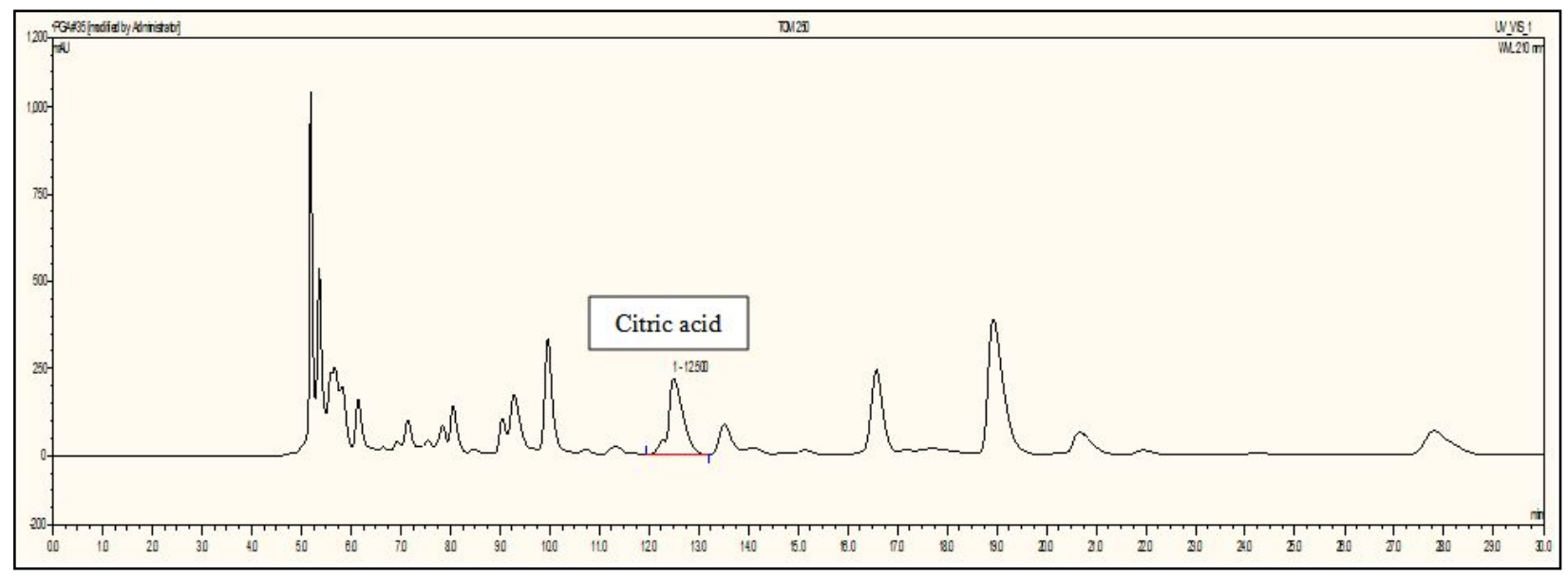

Figure S14b. depicts the detection of citric acid in TW2 medium (5X concentrated). 
Table S1. Composition of synthetic production media(B, B1 and B2 media)

\begin{tabular}{|c|c|c|c|c|c|c|}
\hline $\begin{array}{l}\text { Sr. } \\
\text { No. }\end{array}$ & $\begin{array}{l}\text { B medium } \\
\text { components }\end{array}$ & $\begin{array}{c}\text { Concentration } \\
(\mathrm{g} / \mathrm{L})\end{array}$ & $\begin{array}{l}\text { B1 medium } \\
\text { components }\end{array}$ & $\begin{array}{c}\text { Concentration } \\
(\mathrm{g} / \mathrm{L})\end{array}$ & $\begin{array}{l}\text { B2 medium } \\
\text { components }\end{array}$ & $\begin{array}{c}\text { Concentration } \\
(\mathrm{g} / \mathrm{L})\end{array}$ \\
\hline 1 & Glucose & 40 & Glucose & 40 & Glucose & 40 \\
\hline 2 & L-glutamic acid & 20 & $\begin{array}{c}\text { L-glutamic } \\
\text { acid }\end{array}$ & 20 & $\begin{array}{c}\text { L-glutamic } \\
\text { acid }\end{array}$ & 20 \\
\hline 3 & Citric acid & 10 & Citric acid & 10 & Citric acid & 10 \\
\hline 4 & $\mathrm{NH}_{4} \mathrm{Cl}$ & 6 & $\begin{array}{c}\text { Ammonium } \\
\text { nitrate }\end{array}$ & 6 & $\begin{array}{c}\text { Ammonium } \\
\text { nitrate }\end{array}$ & - \\
\hline 5 & $\mathrm{~K}_{2} \mathrm{HPO}_{4}$ & 1 & $\mathrm{~K}_{2} \mathrm{HPO}_{4}$ & 1 & $\mathrm{~K}_{2} \mathrm{HPO}_{4}$ & - \\
\hline 6 & $\mathrm{MgSO}_{4}, .7 \mathrm{H}_{2} \mathrm{O}$ & 0.5 & $\mathrm{MgSO}_{4}, 7 \mathrm{H}_{2} \mathrm{O}$ & 0.5 & $\mathrm{MgSO}_{4}, 7 \mathrm{H}_{2} \mathrm{O}$ & - \\
\hline 7 & $\mathrm{CaCl}_{2} \cdot 2 \mathrm{H}_{2} \mathrm{O}$ & 0.2 & $\mathrm{CaCl}_{2} \cdot 2 \mathrm{H}_{2} \mathrm{O}$ & 0.2 & $\mathrm{CaCl}_{2} \cdot 2 \mathrm{H}_{2} \mathrm{O}$ & - \\
\hline 8 & $\mathrm{FeCl}_{3} \cdot 7 \mathrm{H}_{2} \mathrm{O}$ & 0.03 & $\mathrm{FeCl}_{3} \cdot 7 \mathrm{H}_{2} \mathrm{O}$ & 0.03 & $\mathrm{FeCl}_{3} \cdot 7 \mathrm{H}_{2} \mathrm{O}$ & - \\
\hline
\end{tabular}

Table S2. Composition of tomato waste media (TW1\& TW2)

242

\begin{tabular}{|c|c|c|c|c|}
\hline $\begin{array}{c}\text { Sr. } \\
\text { No. }\end{array}$ & $\begin{array}{c}\text { TW1 } \\
\text { Components }\end{array}$ & Composition(g/L) & $\begin{array}{c}\text { TW2 } \\
\text { Components }\end{array}$ & Composition(g/L) \\
\hline 1 & Tomato waste & $\begin{array}{c}\text { Concentrated } 1 \mathrm{X} \text { to } \\
5 \mathrm{X}\end{array}$ & Tomato waste & Concentrated 1X to $5 \mathrm{X}$ \\
\hline 2 & $\begin{array}{c}\text { Ammonium } \\
\text { nitrate }\end{array}$ & 6 & Ammonium nitrate & - \\
\hline 3 & $\mathrm{~K}_{2} \mathrm{HPO}_{4}$ & 1 & $\mathrm{~K}_{2} \mathrm{HPO}_{4}$ & - \\
\hline 4 & $\mathrm{MgSO}_{4}, 7 \mathrm{H}_{2} \mathrm{O}$ & 0.5 & $\mathrm{MgSO}_{4}, 7 \mathrm{H}_{2} \mathrm{O}$ & - \\
\hline 5 & $\mathrm{CaCl}_{2} .2 \mathrm{H}_{2} \mathrm{O}$ & 0.2 & $\mathrm{CaCl}_{2} .2 \mathrm{H}_{2} \mathrm{O}$ & - \\
\hline 6 & $\mathrm{FeCl}_{3} .7 \mathrm{H}_{2} \mathrm{O}$ & 0.03 & $\mathrm{FeCl}_{3} .7 \mathrm{H}_{2} \mathrm{O}$ & - \\
\hline
\end{tabular}

247 
(1) Khalil, I. R.; Khechara, M. P.; Kurusamy, S.; Armesilla, A. L.; Gupta, A.; Mendrek, B.; Khalaf, T.; Scandola, M.; Focarete, M. L.; Kowalczuk, M.; et al. Poly-Gamma-Glutamic Acid ( $\gamma$-PGA)-Based Encapsulation of Adenovirus to Evade Neutralizing Antibodies. mdpi.com. https://doi.org/10.3390/molecules23102565.

(2) Manocha, B.; Nanomaterials, A. M.-J. of; 2010, undefined. Controlled Release of Doxorubicin from Doxorubicin/-Polyglutamic Acid Ionic Complex. hindawi.com.

(3) Wang, D.; Kim, H.; Lee, S.; Kim, D.; factories, M. J.-M. cell; 2020, undefined. High-Level Production of Poly- $\gamma$-Glutamic Acid from Untreated Molasses by Bacillus Siamensis IR10. Springer.

(4) Bhunia, B.; Mukhopadhy, D.; ... S. G.-J. of; 2012, undefined. Improved Production, Characterization and Flocculation Properties of Poly $(\gamma)$-Glutamic Acid Produced from Bacillus Subtilis. search.ebscohost.com.

(5) Minas, K.; McEwan, N.; .. C. N.-F. microbiology; 2011, undefined. Optimization of a High-Throughput CTAB-Based Protocol for the Extraction of QPCR-Grade DNA from Rumen Fluid, Plant and Bacterial Pure Cultures. academic.oup.com.

(6) Hansen, B.; ... T. L.-F. M.; 2001, undefined. Polymerase Chain Reaction Assay for the Detection of Bacillus Cereus Group Cells. academic.oup.com.

(7) Kambourova, M.; Tangney, M.; Priest, F. G. Regulation of Polyglutamic Acid Synthesis by Glutamate in Bacillus Licheniformis and Bacillus Subtilis. Appl. Environ. Microbiol.2001, 67 (2), 1004-1007. https://doi.org/10.1128/AEM.67.2.1004-1007.2001.

(8) Xu, W.; Liang, L.; Zhu, M. Determination of Sugars in Molasses by HPLC Following Solid-Phase Extraction. Int. J. Food Prop.2015, 18 (3), 547-557. https://doi.org/10.1080/10942912.2013.837064.

(9) Agius, C.; Tucher, S. Von; Poppenberger, B.; Molecules, W. R.-; 2018, undefined. Quantification of

(10) Zafar, M.; Arshad, F.; Faizi, S.; Anwar, Z.; ... M. I.-B. and; 2020, undefined. HPLC Based Characterization of Citric Acid Produced from Indigenous Fungal Strain through Single and Co-Culture Fermentation. Elsevier. 